\title{
MODIFIKASI PERILAKU ANAK: IMPLEMENTASI TEKNIK PENGELOLAAN DIRI DAN KETERAMPILAN SOSIAL DI NGAWI JAWA TIMUR
}

\author{
Aziz Nuri Satriyawan ${ }^{1}$ dan Ahmad Shofiyuddin Ichsan ${ }^{2}$ \\ ${ }^{1}$ Sekolah Tinggi Ilmu Tarbiyah Muhammadiyah Tempurrejo Ngawi, \\ ${ }^{2}$ Institut Ilmu Al Qur'an An Nur Yogyakarta \\ Email : aziz.nuri94@gmail.com, ahmad.shofiyuddin.ichsan@gmail.com \\ Website: \\ https://jurnal.uinantasari.ac.id/index.php/adzka \\ Received: 26 Mei 2020; Accepted: 4 Juni 2020; Published: 4 Juni 2020
}

\begin{abstract}
This study aims to uncover how child behavior modification techniques can be changed, that is, changing adaptive behavior towards adaptive behavior. This study is qualitative research which is conducted on children in Kenteng Sumberejo Sine Ngawi East Java with a focus on children who have maladaptive behaviors. The results show that behavior modification techniques through self-management and social skills training are able to change children's behavior, both to anticipate not to behave negatively by eliminating it, or to be able to foster positive behavior for them. Therefore, communication and cooperation between each family members is needed through continuous motivation, understanding and supervision. It is in order to realize the modification of good behavior towards children.
\end{abstract}

Key Words : behavior modification; self-management; social skill

\begin{abstract}
ABSTRAK
Penelitian ini bertujuan untuk mengungkap bagaimana teknik modifikasi perilaku anak dapat diubah, yakni mengubah perilaku maladaptif menuju perilaku adaptif. Penelitian ini adalah penelitian kualitatif yang dilakukan pada anak di Kenteng Sumberejo Sine Ngawi Jawa Timur dengan fokus kepada anak-anak yang memiliki perilaku maladaptif. Hasil penelitian ini mengungkapkan bahwa teknik modifikasi perilaku melalui pengelolaan diri dan pelatihan keterampilan sosial mampu mengubah perilaku anak, baik untuk mengantisipasi supaya tidak berperilaku negatif dengan menghilangkannya, maupun dapat menumbuh kembangkan perilaku yang positif bagi mereka. Maka dari itu, diperlukan komunikasi dan kerja sama antar masing-masing anggota keluarga melalui motivasi, pengertian, dan pengawasan yang dilakukan secara kontinyu. Hal ini demi terwujudnya modifikasi perilaku yang baik terhadap anak.
\end{abstract}

Kata Kunci: modifikasi perilaku; pengelolaan diri; keterampilan sosial

\section{PENDAHULUAN}

Pendidikan karakter tidak hanya berkaitan dengan konteks benar dan salah, tetapi bagaimana pendidikan ini mampu menanamkan kebiasaan yang baik dalam kehidupan keseharian. Melalui hal tersebut, peserta didik lebih menyadari dan memahami secara komprehensif dalam dirinya, serta lebih peduli dan memiliki komitmen untuk melakukan kebaikan-kebaikan dalam kehidupannya. Di titik ini, maka pendidikan karakter memiliki makna yang lebih dalam dan lebih tinggi dibanding dengan pendidikan moral itu sendiri. Pendidikan karakter memiliki sifat alami dari diri manusia dalam merespon hal-hal atau situasi yang ada di sekitarnya secara bermoral dengan perwujudan tindakan nyata, seperti berperilaku baik, jujur, hormat terdapat orang lain (lebih-lebih terhadap orang yang tua), 
bertanggung jawab, dan perilaku-perilaku yang baik lainnya. (Mulyana, 2016:3). Untuk itu, menjadi penting bagaimana pendidikan karakter ini harus ditanamkan kepada anak sejak dini mungkin.

Anak di kelas awal Sekolah Dasar (SD) merupakan anak yang berada pada rentang usia dini. Usia ini merupakan masa usia yang pendek, tetapi justru menjadi masa terpenting bagi kehidupan manusia. Pada masa usia dini ini, seluruh potensi yang dimiliki anak perlu dilatih dan didorong secara benar dan tepat, sehingga anak akan tumbuh dan berkembang sebagai manusia yang utuh. Tentu dalam konteks ini, yang terbaik adalah menanamkan sedini mungkin pada pendidikan karakter dalam dirinya.

'Masa usia emas' tersebut saatnya anak lebih diajarkan bagaimana mentaati kedua orang tua, guru, dan orang di sekitar yang lebih tua darinya dan menyayangi yang lebih muda, dan sikap positif lainnya. Tidak hanya itu, dalam pendidikan Islam, ketika anak sudah memasuki usia tamyiz, orang tua tidak boleh membiarkan anak meninggalkan aturan agama, seperti meninggalkan sholat lima waktu. Anak juga mulai diajarkan taat menjalankan agama, seperti berpuasa di bulan ramadan, bersedekah, dan seterusnya. Ini yang menjadi hal utama yang perlu diperhatikan oleh orang tua dan dijaga sebaik-baiknya. Karena bagaimanapun, seorang anak merupakan fitrah yang telah diciptakan Tuhan sebaik-baiknya, sehingga anak akan siap menerima segala pendidikan yang diajarkannya, baik itu berbentuk pilihan kebaikan maupun keburukan. Maka dalam Islam, kedua orang tualah yang menjadikannya pada kecenderungan salah satu dari pilihan tersebut. Sebagaimana sabda Rasulullah Saw:

$$
\text { كلّ مولود يولد علي الفطرة, فأبو اه يمّودانه أو ينصّر انه أو يمجّسانه }
$$

Artinya: "Setiap anak terlahir dalam keadaan fitrah (suci). Maka kedua orang tuanyalah yang menjadikannya sebagai Yahudi, Nasrani, ataupun Majusi." HR.Abu Hurairah. (Abdurrahman, 2010: xx)

Hadis tersebut menekankan bahwa fitrah yang dibawa anak sejak lahir sangat besar dipengaruhi oleh lingkungan di sekitarnya. Dalam artian, lingkungan mampu memodifikasi secara drastis kehidupan kepribadian anak. Lingkungan sebagai faktor eksternal mampu mempengaruhi sifat dasar anak. Maka dari itu, fitrah tidak akan berkembang tanpa adanya pengaruh lingkungan, sehingga baik dan buruk kepribadian anak tergantung bagaimana faktor eksternalnya tersebut berperan (Aisyah, 2019:58).

Pertumbuhan fisik pada anak usia SD memiliki karakteristik perkembangan yang telah matang. Anak di usia tersebut mampu mengontrol fisik tubuhnya serta menyeimbangkannya. Dalam artian, anak bisa melompat dengan kaki secara bergantian, menangkap benda-benda (seperti bola), dan bisa berkoordinasi antara tangan, mata, dan pikirannya dalam memegang pensil dan menuliskannya di atas kertas. Tidak hanya itu, perkembangan sosial anak pada usia SD itu telah menunjukkan ke-aku-annya, baik tentang jenis kelaminnya, berkompetisi dengan temannya, bersahabat, berbagi dengan orang lain, dan mulai mandiri (Majid, 2014:16).

Secara umum, keluarga merupakan sumber pendidikan pertama, bahkan keluarga merupakan sumber pendidikan moral bagi anaknya dimulai. Maka tidak jarang banyak menyebutkan bahwa orang tua adalah guru pertama dalam pendidikan moral dan etika kepada anak-anaknya di rumah. Orang tua telah memberikan pengaruh terlama terhadap perkembangan moral anak. Para guru di sekolah mungkin akan berubah pada setiap tahunnya, tetapi ketika di luar sekolah, orang tua lah yang memberikan bimbingan secara penuh selama proses membesarkan anak-anaknya selama bertahun-tahun, bahkan sampai dewasa (Lickona, 2013:48).

Perilaku merupakan segala sesuatu yang dilakukan manusia. Perilaku memiliki satu atau lebih dimensi yang dapat diukur, baik durasi maupun intensinya. Perilaku juga dapat 
digambarkan, dicatat, dan diukur oleh siapapun. Setiap perilaku manusia memiliki dampak terhadap lingkungan sosialnya. Ia akan mengikuti hukum dalam prinsip belajar. Dalam pandangan behavioral, diasumsikan bahwa perilaku, baik itu baik maupun buruk, merupakan hasil belajar. Dalam konteks yang lain, perilaku yang tidak baik (maladaptif) merupakan hasil belajar yang keliru dan ia dapat diubah dan diarahkan ke arah proses belajar yang benar. Perilaku maladaptif adalah perilaku tidak baik yang ditampilkan seseorang yang tidak sesuai dengan lingkungan masyarakat. Hal ini terjadi dikarenakan ketidakmampuan seseorang dalam mengartikan sesuatu yang terjadi pada dirinya sehingga akan merugikan perkembangan orang itu sendiri.

Salah satu cara untuk penanganan perilaku maladaptif pada anak adalah dengan melakukan modifikasi perilaku. Modifikasi perilaku merupakan salah satu teknik perubahan tingkah laku seseorang. Teknik ini sering digunakan karena keberhasilannya mudah dilihat serya mudah diimplementasikan ke perilaku lainnya dalam kehidupan sehari-hari. Modifikasi perilaku mempunyai dua tujuan. Pertama, mendukung dan mempromosikan perilaku anak yang adaptif. Kedua, modifikasi perilaku bertujuan menekan atau meniadakan munculnya perilaku anak yang tidak adaptif (Purwanta, 2013:3).

Modifikasi perilaku ini digunakan secara sistematis dalam konteks teknik kondisioning (memposisikan) manusia dalam menghasilkan perubahan perilaku tertentu. Menurut Eysenck, modifikasi perilaku merupakan usaha sadar yang bertujuan mengubah perilaku manusia dan emosinya dengan cara menguntungkan, karena berdasarkan pada teori modern proses belajar. Di sini, modifikasi perilaku sebagai sebuah penerapan prinsip belajar yang telah diuji secara eksperimen dalam rangka mengubah perilaku manusia yang tidak adaptif (maladaptif). Penerapannya dilakukan dengan cara kebiasaan perilaku maladaptif seseorang dilemahkan dan perilaku adaptif ditampakkan dan dikukuhkan. Dalam realitas kehidupan, khususnya di Kecamatan Sine Kabupaten Ngawi, banyak anak yang memiliki kebiasaan yang buruk dari lingkungannya, yakni kebiasaan tidur malam, sehingga akan kesiangan dalam bangun paginya, kebiasaan berkata kotor kepada orang lain, dan kebiasaan-kebiasan buruk lainnya. Hal ini mencerminkan bahwa kehidupan keseharian ini telah terjadi maladaptif sehingga perlu dilakukan perbaikan-perbaikan dalam diri untuk mengembalikan anak ke ranah kehidupan adaptif. Maka dari itu, melihat realitas tersebut, diperlukan modifikasi perilaku sebagai solusi untuk memperbaiki moral dan karakter diri anak-anak tersebut.

Adapun beberapa manfaat modifikasi perilaku dapat dilihat sebagai berikut : Pertama, langkah-langkah modifikasi perilaku dapat direncanakan, didiskusikan, dan dimintai persetujuan terlebih dahulu dari orang-orang yang terlibat di dalamnya. Hal ini supaya hasil yang didapatkan lebih kooperatif. Kedua, perincian implementasinya dapat diubah sesuai kebutuhan situasi dan kondisi. Ketiga, hasil monitoring dapat terdeteksi dan dicari teknik solusi pengganti jika dari modifikasi tersebut ada yang gagal. Keempat, teknik ini dapat diterangkan dan diatur secara rasional sehingga dapat dievaluasi secara objektif. Kelima, waktu yang dibutuhkan dalam proses modifikasi lebih singkat.

Berdasarkan uraian tersebut, menjadi penting untuk ditelaah dan dianalisis secara komprehensif bagaimana perubahan tingkah laku seseorang (dalam hal ini adalah anak-anak usia SD) dengan menggunakan teknik modifikasi perilaku. Hal tersebut memiliki tujuan di antaranya: 1). Menjadi khazanah pengetahuan tersendiri bagi dunia pendidikan bagaimana maladaptif anak bisa dirubah ke arah lebih baik melalui teknik modifikasi perilaku, 2). Menjadikan perhatian bagi orang tua dan sekolah sebagai salah satu solusi dalam mengatasi kenakalan anak di usia sekolah, khususnya di Sekolah Dasar.

\section{METODE PENELITIAN}

Penelitian ini termasuk penelitian kualitatif yang memiliki tujuan untuk mendeskripsikan perubahan perilaku pada anak. Subjek penelitian merupakan orang yang 
dijadikan informan yang berfungsi sebagai pemberi informasi terkait situasi dan kondisi selama penelitian berlangsung. Adapun informan utama yang dijadikan sebagai subjek penelitian adalah: anak, orang tuanya, dan tetangga terdekat. Sedangkan objek penelitian ini adalah di Dusun Kenteng, Desa Sumberejo. Kecamatan Sine. Kabupaten Ngawi, Provinsi Jawa Timur dengan durasi penelitian satu bulan, yakni Februari 2020. Metode dalam mengumpulkan data pada penelitian ini adalah observasi, wawancara, dan dokumentasi.

Marshall menyatakan bahwa "through observasion, the researcher learn about behavior and the meaning attached to those behavior." Melalui observasi, peneliti belajar tentang perilaku, dan makna dari perilaku tersebut. Dalam pengumpulan data, selain observasi juga dengan wawancara (Sugiyono, 2015:310). Oleh karena itu, berikut akan dijelaskan identitas anak beserta perilaku yang akan diubah:

Tabel 1. Identitas dan Perilaku Anak

\begin{tabular}{|l|l|l|l|}
\hline No & \multicolumn{1}{|c|}{ Nama } & \multicolumn{1}{c|}{ Usia } & \multicolumn{1}{c|}{ Perilaku } \\
\hline 1 & Valentia B.N. & 8 Tahun & $\begin{array}{l}\text { Membiasakan mengucap salam } \\
\text { sebelum masuk rumah/sekolah }\end{array}$ \\
\hline 2 & Muhammad R. & 9 Tahun & $\begin{array}{l}\text { Menghilangkan kebiasaan bermain } \\
\text { game Online }\end{array}$ \\
\hline 3 & Valentino E.Y. & 9 Tahun & $\begin{array}{l}\text { Menghilangkan kebiasaan tidur terlalu } \\
\text { malam }\end{array}$ \\
\hline 4 & Faisal A.A. & 8 Tahun & Membiasakan bangun pagi \\
\hline 5 & Cantika N.N. & 7 Tahun & $\begin{array}{l}\text { Menghilangkan kebiasaan berkata } \\
\text { kasar }\end{array}$ \\
\hline 6 & Kaira H. & 8 Tahun & $\begin{array}{l}\text { Menghilangkan kebiasaan menonton } \\
\text { televisi }\end{array}$ \\
\hline 7 & Isa A. & 7 Tahun & $\begin{array}{l}\text { Menghilangkan kebiasaan } \\
\text { mengganggu dan berkelahi dengan } \\
\text { saudara kandung }\end{array}$ \\
\hline 8 & Intan N.S. & 8 Tahun & $\begin{array}{l}\text { Menghilangkan kebiasaan marah- } \\
\text { marah }\end{array}$ \\
\hline 9 & Farid N.S. & 8 Tahun & $\begin{array}{l}\text { Menghilangkan kebiasaan malas } \\
\text { belajar }\end{array}$ \\
\hline 10 & Yusuf M. & 8 Tahun & $\begin{array}{l}\text { Membiasakan peduli dengan } \\
\text { lingkungan }\end{array}$ \\
\hline
\end{tabular}

Teknik analisis data dalam penelitian ini merujuk pada Miles dan Hubberman, yakni aktivitas analisis data dilakukan secara terus menerus, sehingga datanya jenuh. Analisis data tersebut yaitu reduksi data (data reduction), penyajian data (data display), penarikan kesimpulan (conclusion drawing/Verification) (Sugiyono, 2018:334). Adapun teknik pemeriksaan keabsahan data, peneliti menggunakan uji kredibilitas dengan triangulasi sumber, yakni sumber yang digunakan untuk membandingkan dan mengecek kembali derajat kepercayaan suatu data informasi yang diambil melalui alat dan waktu yang berbeda dalam sebuah penelitian (Moelong, 2011:330).

\section{HASIL PENELITIAN DAN PEMBAHASAN}

\section{A. Teknik Modifikasi Perilaku}

Sebagaimana yang sudah dijelaskan bahwa modifikasi perilaku merupakan segala tindakan yang memiliki tujuan untuk mengubah perilaku seseorang. Modifikasi perilaku ini merupakan sebuah usaha dalam mengimplementasikan prinsip proses belajar atau prinsip 
psikologi hasil eksperimen pada perilaku manusia. Para pegiat teori Behaviors memberikan definisi bahwa modifikasi perilaku sebagai penggunaan sistematis teknik kondisioning manusia dalam menghasilkan perubahan frekuensi dari perilaku sosial tertentu. Dalam artian, ia merupakan tindakan dalam mengontrol lingkungan sosial perilaku seseorang tersebut.

Dalam pemilihan teknik modifikasi perilaku sangat tergantung pada jenis perilaku yang ingin diubah, oleh karena itu, peneliti memilih dua teknik sebagai berikut:

Pertama, Teknik Pengelolaan Diri (Self Management). Menurut Suhartini dalam Makhfud, self management merupakan prosedur yang menuntut seseorang untuk mengatur tingkah lakunya sendiri (Makhfud, 2011:33). Menurut The Liang Gie, teknik pengelolaan diri dapat berarti mendorong diri seseorang sendiri untuk berperilaku maju, mengatur semua unsur kemampuan diri, mengendalikannya dalam mencapai hal-hal yang baik, dan mengembangkan berbagai segi dari kehidupan pribadi agar lebih sempurna (Liang Gie, 2000:77). Ada empat aspek dalam pembentukan Self Management yakni: pendorongan diri (self motivasion), penyusunan diri (self organisasion), pengendalian diri (self control), dan pengembangan diri (self development).

Kedua, Pelatihan Keterampilan Sosial. Ini merupakan kemampuan seseorang dalam memecahkan masalah, sehingga ia bisa beradaptasi secara harmonis dengan masyarakat di sekelilingnya. Keterampilan sosial, menurut Gresham dan Elliot, merupakan perilaku dalam konteks situasi tertentu yang bisa memprediksi hasil interaksi sosial yang penting bagi seseorang, seperti penilaian orang lain, teman sebaya, popularitas, dan tingkah laku sosial lain yang ada keterkaitan secara konsisten. Oleh karena itu, keterampilan sosial ini sebagai perilaku dapat menunjukkan hubungan interpersonal yang memiliki penguatan dalam fungsi sosial. Maka setidaknya terdapat empat aspek untuk melatih keterampilan sosial dalam kehidupan seseorang, yakni: perilaku terhadap lingkungan (environmental behavior), perilaku interpersonal (interpersonal behavior), perilaku yang berhubungan dengan diri sendiri (self related behavior), dan perilaku yang berhubungan dengan tugas (taks related behavior)

\section{B. Hasil Perubahan Perilaku Anak}

Hasil penelitian penelitian menunjukkan bagaimana hasil perubahan perilaku anak selama tindakan modifikasi perilaku dilakukan. Oleh karenanya, peneliti akan menguraikan secara lebih detail dari satu observasi ke observasi lainnya, yakni observasi satu anak ke anakanak lainnya. Hal ini dilakukan untuk memudahkan dalam memahami tindakan modifikasi perilaku pada anak-anak usia Sekolah Dasar.

Hasil perubahan dari modifikasi perilaku ini juga tidak terlepas dari tanggung jawab orang tua anak dengan berbagai cara, yakni: 1). Adanya kesadaran orang tua dalam mendidik dan membina anak secara terus menerus, 2). Orang tua memahami pentingnya tata cara mendidik anak, dan 3). Orang tua juga meningkatkan kemampuan pengetahuan dan keterampilan sebagai pendidik pertama untuk anak-anaknya secara kontinyu (Sulistyoko, 2018:182).

\section{Observasi Pertama}

Sekitar pukul 14.00 WIB, peneliti berkunjung ke rumah adik Bima dan diterima oleh orang tuanya. Tetapi ketika itu, Bima sedang tidur siang dan orang tuanya menyarankan supaya peneliti datang kembali besok. Keesokan harinya, sekitar pukul 15.00 peneliti memulai observasi dengan mengamati kegiatan Bima di sekitar rumahnya. Observasi hari pertama ini, peneliti melakukan komunikasi dan meminta persetujuan dengan orang tua Bima terkait pelaksanaan modifikasi perilaku yang akan dilakukan untuk membiasakan mengucap salam dan menyapa orang lain ketika berjumpa di jalan. Orang tua Bima sepakat dan membantu merealisasikan modifikasi perilaku tersebut. Melalui kesepakatan tersebut, orang tua Bima secara terus menerus mengawasi dan mengingatkannya secara konsisten ketika mau masuk rumah harus mengucapkan salam. Minggu pertama belum terlihat perubahan perilaku 
pada Bima secara signifikan. Peneliti melakukan observasi hari kedua, modifikasi tetap dilakukan sampai minggu-minggu berikutnya. Akhirnya selama tiga minggu observasi dilakukan, Bima memiliki perubahan perilaku dengan mulai mengucap salam ketika masuk rumah dan menyapa orang lain ketika berjumpa dengan orang lain.

Berdasarkan hasil wawancara peneliti dengan Bima, didapatkan bahwa anak laki-laki berusia 8 tahun itu selama ini tinggal bersama ayah dan ibunya. Sebelumnya, ia memiliki kebiasaan tidak mengucap salam ketika masuk rumah dan tidak menyapa orang lain. Hasil observasi selama tiga minggu, akhirnya Bima mengalami perubahan. Bahkan ia merasa senang sekali adanya pelaksanaan modifikasi perilaku ini, diperkuat adanya motivasi dan perhatian orang tuanya kepada Bima. Hal tersebut memberikan penyadaran kepada Bima tentang bagaimana pentingnya menolong, rasa empati kepada sesama, dan menyapa orang lain. Karena dengan penyadaran tersebut, ia lebih mengerti arti bagaimana menggunakan ilmu dan bersosial secara baik. Maka dari itu, pelaksanaan modifikasi perilaku ini mampu mengubah perilaku Bima menjadi perilaku yang positif (adaptif) (Wawancara Personal dengan Bima, 22 Februari 2020).

\section{Observasi Kedua}

Hari Senin tepat pukul 14.00 WIB, peneliti berkunjung ke rumah Ridwan. Terlihat ia sedang asyik bermain dengan teman sebayanya. Dari situ, peneliti mulai observasi dengan mengamati kegiatan Ridwan Hasil pengamatan awal, Ridwan termasuk anak pandai, rajin, dan tidak pernah bolos sekolah. Dengan dukungan fasilitas rumah yang memadai, aktifitas orang tua Ridwan justru sangat padat, sehingga kegiatan Ridwan di rumah kurang terkontrol dengan baik. Observasi hari pertama ini, peneliti melakukan persetujuan/komunikasi dengan orang tua Ridwan terkait terlaksananya modifikasi perilaku yang akan dilakukan untuk mengurangi/menghilangkan kebiasaan bermain game online di rumah. Orang tuanya sangat menyetujui untuk membantu peraturan modifikasi yang akan diterapkan.

Hal pertama yang harus dilakukan adalah menjadwal kegiatan sehari-hari, mulai dari bangun tidur sampai tidur kembali, mencatat semua kegiatan yang akan dilakukan pada lembar pengingat yang ditempel di dinding Penyusunan diri ini merupakan pengaturan terbaik terhadap pikiran, tenaga, waktu, sehingga tercapai kehidupan individu menjadi lebih efektif. Di sini, orang tua terus bekerjasama untuk mengawasi dan mengingatkan Ridwan saat bermain Game Online. Hal ini seperti mengingatkan waktu shalat, waktu belajar, waktu mengerjakan PR, dan seterusnya. Pada akhirnya, observasi pada minggu pertama sudah mengurangi kebiasaan Ridwan bermain game online.

Observasi hari kedua, modifikasi tetap dilakukan dan iawasi oleh kedua orang tuanya dengan mengajak bermain bersamanya serta mendampingi Ridwan saat belajar dan mengerjakan PR. Kegiatan ini mampu menurunkan kebiasaan Ridwan bermain game Online secara lebih signifikan. Pada observasi hari ketiga, bentuk ajakan bermain dan pendampingan saat anak belajar masih diterapkan dan memberikan hasil perubahan yang lebih baik, yakni penurunan/menghilangkan kebiasaan bermain game Online (Wawancara Personal dengan Ridwan, 3 Februari 2020).

Dengan adanya modifikasi perilaku, saat ini perasaan Ridwan senang, apalagi diperkuat adanya perhatian lebih dari orang tuanya. Maka dari kasus ini, peneliti mencoba mengobservasi hampir berjalan selama empat minggu. Oleh karena itu, tidak hanya Ridwan yang merasakan manfaat adanya modifikasi ini, tetapi orang tuanya juga menilai modifikasi perilaku ini efektif untuk mengubah perilaku menuju perilaku yang lebih baik kepada anak, khususnya anak yang memiliki kebiasaan kurang baik. 


\section{Observasi Ketiga}

Pada hari Minggu pukul 09.00 WIB, peneliti berkunjung ke tempat Valentino. Menurut orang tuanya, ia sering tidur larut malam. Pada observasi hari pertama, peneliti melakukan komunikasi dan kerjasama dengan orang tua terkait pelaksanaan modifikasi perilaku untuk menurunkan kebiasaannya tersebut. Dengan adanya kesepakatan, orang tua setuju untuk mengendalikan diri Valentino untuk lebih teratur dalam tidurnya. Pengendalian diri sendiri merupakan sebuah perbuatan dalam konteks membina tekad, mendisiplinkan kemauan, dan mengarahkan untuk melaksanakan apa yang harus dilakukan. Observasi hari kedua belum memberikan dampak penurunan. Peneliti tetap melakukan tahapan demi tahapan sampai pada minggu berikutnya. Orang tua mulai rajin mengingatkan supaya aktifitasnya dihentikan karena sudah masuk waktu istirahat. Orang tua juga memberikan penjelasan kepada Valentino tentang tidur larut malam kurang baik bagi kesehatannya. Hal ini terus dilakukan secara konsisten. Pada observasi hari ketiga, akhirnya kebiasaan Valentino tidur larut malam mulai berkurang.

Hasil wawancara disebutkan bahwa Valentino merupakan anak pertama dari dua saudara. Hasil pelaksanaan modifikasi perilaku yang ditujukan ke ia selama tiga minggu memberikan penyadaran kepadanya bahwa ia lebih paham tentang pentingnya menjaga kesehatan. Artinya, pelaksanaan modifikasi perilaku ini mampu mengubah perilaku Valentino menjadi perilaku yang positif dan meninggalkan perilaku yang ianggap kurang baik sebelumnya (Wawancara Personal dengan Valentino, 22 Februari 2020).

\section{Observasi Keempat}

Pada Minggu 29 Februari 2020 pukul 16.00 WIB, peneliti berkunjung ke rumah Faisal. Ketika itu Faisal sedang asyik bermain dengan kakak-kakaknya. Peneliti memulai observasi dengan mengamati kegiatan Faisal Menurut hasil observasi, ia sering sekali tidur tidak terkontrol, sehingga selalu bangun kesiangan. Observasi hari pertama, peneliti berkomunikasi dan bekerja sama dengan orang tua Faisal demi terlaksananya modifikasi perilaku. Penerapan modifikasi ini membutuhkan waktu tiga minggu. Pada minggu pertama, ia belum begitu nampak perilaku yang cenderung berubah. Observasi kedua, peneliti mencoba memberikan motivasi dan penjelasan tentang pentingnya bangun pagi bagi kesehatan serta orang tua akan menambah 'reward', yakni menyajikan makanan kesukaannya. Hal tersebut mampu menurunkan kebiasaan bangun siangnya.

Observasi hari ketiga, motivasi dan pengertian tentang pentingnya bangun pagi bagi kesehatan secara konsisten dan terus menerus dilakukan sehingga mampu memberikan dampak perubahan perilakunya ke arah lebih baik. Hasil adanya pelaksanaan modifikasi perilaku tersebut, Faisal tampak bahagia. Baginya, ia senang karena selama pelaksanaan tersebut juga ada motivasi, penjelasan pentingnya bangun pagi bagi kesehatan dan pemberian reward. Oleh karena itu, bagi orang tua Faisal, modifikasi perilaku ini sangat efektif karena telah membantu mengubah perilaku anaknya menuju perilaku yang lebih baik, padahal sebelumnya untuk merubahnya sangat susah (Wawancara Personal dengan Faisal, 29 Februari 2020).

\section{Observasi Kelima}

Observasi kelima ini peneliti berkunjung ke rumah Naya. Ketika itu, ia sedang menonton televisi bersama keluarga. Peneliti melakukan observasi awal dengan mengamati kegiatannya. Hasil observasi, Naya adalah anak yang rajin dan baik, namun pergaulan yang salah mengakibatkan cara berkomunikasinya kurang terkontrol. Sebagai perempuan, perbuatannya tidak lazim dilakukan. Ia memiliki kebiasaan berkata kasar, baik kepada teman sebayanya maupun kepada keluarga. Observasi hari pertama, peneliti berkomunikasi dan mendiskusikan dengan orang tua Naya untuk melakukan modifikasi perilaku, yakni dengan 
mengajak orang tua bekerja sama untuk memberikan motivasi dan penjelasan kepadanya. Sampai pada observasi hari ketiga, yang didukung dengan pemberian motivasi dan pengertian tentang belajar bahasa yang boleh digunakan (kata-kata yang baik/sopan) secara konsisten dan terus menerus oleh orang tua Naya, sedikit demi sedikit kata-kata kasar Naya mulai berkurang dan mulai muncul kebiasaan berkata baik/sopan kepada orang lain, khususnya kepada orang tua.

Secara garis besar, hasil yang didapatkan dapat dijelaskan bahwa Naya adalah anak perempuan berusia 7 tahun. Ia memiliki kebiasaan berkata kasar (tidak sopan) orang lain. Faktor utama masalah ini adalah kesalahan dalam memilih pergaulan. Observasi dilakukan sekitar empat minggu, akhirnya modifikasi perilaku bagi Naya sangat bagus untuk diterapkan, karena di sana ada pemberian motivasi dan penjelasan secara detail tentang bagaimana belajar bahasa yang boleh digunakan (kata-kata yang baik/sopan), termasuk nada yang pantas ketika berkomunikasi dengan yang lebih tua. Dengan adanya itu, Naya saat ini mampu mengubah dirinya menjadi pribadi yang lebih baik dan menjalani pergaulan yang lebih positif (Wawancara Personal dengan Naya, 3 Maret 2020).

\section{Observasi Keenam}

Pada hari Minggu pukul 09.00 WIB, peneliti berkunjung ke rumah Kaira. Waktu itu, Kaira sedang diajak pamannya berlibur ke kebun teh Jamus. Keesokan harinya, pada Senin sesuai perjanjian, peneliti berkunjung kembali ke rumah Kaira pada pukul 14.30 WIB. Peneliti mulai observasi awal dengan mengamati kegiatan Kaira. Hasil observasi awal, Kaira anak yang baik dan ramah, namun kebiasaan Kaira adalah keseringan menonton televisi.

Peneliti melalui observasi mencoba menggunakan teknik pengelolaan diri. Observasi hari pertama, peneliti berkomunikasi dan mendiskusikan dengan orang tua Kaira untuk pelaksanaan modifikasi perilaku ini dalam hal bagaimana melakukan pengelolaan diri. Pengorganisasian diri merupakan suatu usaha dalam mengatur segala hal yang mencangkup pikiran, waktu, tempat. Jika segala sesuatu telah diatur sebaik mungkin, maka akan tercapai kehidupan individu yang lebih baik. Persetujuan orang tua sangat membantu berjalannya modifikasi perilaku yang dilakukan, yakni menerapkan aturan tidak boleh menonton televisi sejak mulai pukul 18.00 WIB sampai pukul 21.00 WIB. Waktu ini harus digunakan untuk membaca Al-Qur'an, belajar, dan mengerjakan PR. Demi kelancaran modifikasi perilaku, di sini orang tua Naya harus mengawasi dan melakukan pendampingan saat anak membaca $\mathrm{Al}$ Quran, belajar maupun mengerjakan PR.

Pada observasi hari ketiga dan keempat, orang tua Kaira konsisten secara terus menerus dalam memberikan motivasi dan pengawasan. Modifikasi perilaku ini memberikan dampak yang baik bagi Kaira, yakni menurunkan dan menghilangkan kebiasaan menonton televisi secara berlebihan. Hasil ini dapat dijelaskan bahwa adanya pelaksanaan pengendalian diri, Kaira sangat nyaman dengan adanya pelaksanaan modifikasi perilaku ini. Karena baginya, ia lebih paham tentang pentingnya memanfaatkan waktu ke hal-hal yang baik dan lebih mengutamakan apa yang menjadi prioritasnya (Wawancara Personal dengan Kaira, 1 Maret 2020).

\section{Observasi Ketujuh}

Observasi ketujuh ini peneliti berkunjung ke rumah Isa. Kemudian peneliti mengawali observasi dengan mengamati kegiatan Isa sehari-hari. Ia adalah anak kedua dari dua bersaudara. Dari observasi awal, salah satu faktor Isa sering berkelahi dengan saudaranya adalah kurangnya perhatian dan kasih sayang orang tua terhadap anaknya. Hal ini disebabkan padatnya aktivitas orang tuanya. Isa memiliki kebiasaan mengganggu dan berkelahi dengan saudara kandungnya, salah satu alasannya biasanya adalah berebut mainan. Di sini, melalui observasi hari pertama, peneliti berkomunikasi dan bekerjasama dengan orang tua Isa untuk 
melakukan modifikasi perilaku supaya menurunkan kebiasaan Isa mengganggu saudara kandungnya tersebut.

Dari komunikasi tersebut, orang tua mulai mencoba meluangkan waktu untuk menghindari rasa pilih kasih dan tidak terlalu memuji atau membandingkan masing-masing anaknya Hal ini dikarenakan akan menimbulkan kecemburuan anak satu sama lain. Oleh peneliti, setiap minggu dilakukan pengamatan sampai pada minggu keempat. Dari minggu ke minggu kebiasaan Isa mengganggu dan berkelahi dengan saudaranya mulai menurun, dengan ditambah beberapa motivasi dan penjelasan tentang pentingnya kasih sayang sesama saudara kandung oleh orang tua Isa. Pada observasi hari keempat, memberikan dampak perubahan perilaku yang baik, yakni penurunan dan menghilangkan perilaku mengganggu dan berkelahi dengan saudara kandungnya. Bahkan melalui hasil wawancara dengan Isa, saat ini ia lebih paham tentang pentingnya kebersamaan dan kasih sayang sesama saudara kandungnya (Wawancara Personal dengan Isa, 7 Februari 2020).

\section{Observasi Kedelapan}

Selanjutnya, peneliti berkunjung ke rumah Intan. Observasi hari pertama peneliti mendiskusikan tujuan modifikasi perilaku kepada keluarga Intan. Selanjutnya peneliti melakukan observasi dengan mengamati aktifitas Intan. Menurut peneliti, anak ini memiliki kebiasaan yakni mudah marah (ngambekan). Observasi hari kedua, kami bekerja sama dengan orang tua Intan demi terlaksananya modifikasi perilaku, yakni dengan mengetahui terlebih dahulu apa penyebab kemarahannya.

Setelah diketahui penyebab ia marah dan dicari solusi terbaik untuk menyelesaikan masalah tersebut, maka observasi hari ketiga, kebiasaan Intan mudah marah itu mulai menurun. Melihat sikap anaknya itu, orang tua Intan terus memantau dan mengawasi secara konsisten. Di sini, orang tua mulai menyadari bahwa pada dasarnya seorang anak memang ingin diperhatikan Orang tua harus melakukan apapun kepada anaknya dengan penuh kasih sayang. Sehingga didapati pada observasi keempat, pemberian motivasi dan pengawasan terhadap Intan secara konsisten mampu memberikan dampak perubahan perilakunya, yakni penurunan atau menghilangkan kebiasaan mudah marah. Dari titik itu pula, orang tua menyadari kekurang perhatiannya terhadap anaknya, sehingga mereka mengagendakan waktu khusus bersama demi terjalinnya komunikasi yang hangat antara anak dan orang tua (Wawancara Personal dengan Intan, 6 Februari 2020).

\section{Observasi Kesembilan}

Peneliti berkunjung ke rumah Farid. Sampai di rumah, ia terlihat sedang bermain bersama temannya. Orang tua menyarankan kepada peneliti supaya datang kembali besok pagi karena besok adalah hari libur. Keesokan harinya, sesuai perjanjian, peneliti berkunjung kembali dan langsung melakukan observasi dengan mengamati kegiatan Intan. Hasil observasi awal, peneliti meminta persetujuan orang tua Farid untuk melaksanakan modifikasi perilaku. Adapun modifikasi perilaku ini menggunakan teknik pengelolaan diri yang membuat seseorang bertekad untuk mendisiplinkan kemauan, memacu semangat, mengikis keseganan, dan mengarahkan untuk melaksanakan apa yang harus dikerjakan. Setelah arahan disambut baik, kemudian orang tua membangun komunikasi secara hangat dengan Farid dan diajak untuk menentukan tujuan belajar.

Observasi kedua, orang tua Farid mengawasi dan membimbing serta penjelasan tentang pentingnya belajar sejak dini untuk menggapai cita-citanya kelak secara konsisten dan terus menerus supaya suasana belajarnya menyenangkan. Observasi ketiga, menambah reward (hadiah) dengan membelikannya sepatu baru. Di titik, perilaku Farid mulai berubah sehingga mampu menurunkan sifat malas dalam dirinya. Hasil pelaksanaan modifikasi perilaku melalui pengendalian diri ini dapat memberikan penguatan diri pada individu supaya mampu 
menghindari dirinya pada hal-hal yang tidak penting dan lebih mengutamakan apa yang menjadi prioritasnya, yang dalam hal ini adalah kewajiban seorang siswa untuk giat belajar. Pada observasi terakhir, yakni observasi keempat, orang tua masih melakukan reward kepada Farid dan itu masih memberikan dampak positif baginya. Melalui hasil wawancara, Farid mulai menjadi pribadi yang rajin belajar dan lebih semangat untuk menggapai cita-citanya kelak (Wawancara Personal dengan Farid, 2 Maret 2020).

\section{Observasi Kesepuluh}

Observasi kesepuluh ini adalah observasi terakhir peneliti. Peneliti berkunjung ke rumah Yusuf. Terlihat ia sedang asyik bermain game online. Di sini peneliti mengawali observasi dengan mengamati kegiatan Yusuf secara detail. Hasil observasi awal, Yusuf memiliki perilaku tidak peduli (cuek) dengan lingkungan sekitar. Observasi hari pertama tersebut peneliti berkomunikasi dengan orang tuanya supaya bekerjasama terkait pelaksanaan modifikasi perilaku yang akan dilakukannya. Orang tua diminta untuk mengajak anaknya sering berkunjung dan bercengkerama dengan tetangga dan teman dekat Dengan hal itu, akan menumbuhkan pribadi anak yang peduli terhadap keluarga dan orang lain. Orang tua juga harus menyadari bahwa perilaku anak yang tidak peduli dapat menjauhkan anak dari temantemannya.

Observasi hari kedua, orang tua mengajarkan komunikasi yang baik, memberikan motivasi dan memberikan pengertian tentang pentingnya peduli terhadap lingkungan sekitar. Observasi ketiga, modifikasi perilaku tetap dilakukan, orang tua mengawasi dan mendampingi secara konsisten, sehingga terjadi penurunan perilaku tidak peduli terhadap lingkungan sekitar. Pada observasi keempat, ada peningkatan perilaku Yusuf ke arah yang lebih baik, yakni menjadi pribadi yang lebih mengenal orang di sekitarnya, ia mulai peduli terhadap orang lain dan lingkungan.

Dari hasil wawancara didapatkan bahwa Yusuf sangat senang dengan pelaksanaan modifikasi perilaku ini, karena mampu mengubah perilakunya menjadi pribadi yang lebih baik. Yusuf sadar tentang pentingnya bersilaturrahmi, rasa simpati terhadap sesama Dari sini, orang tua Yusuf memberikan nilai positif terhadap perlaksanaan modifikasi perilaku ini, karena mampu mengurangi kebiasaan Yusuf bermain game online dan kebiasaan menghabiskan waktu bersama media sosialnya (Wawancara Personal dengan Yusuf, 8 Februari 2020).

Dari hasil observasi dapat dijelaskan bahwa adanya beberapa perubahan perilaku menggunakan teknik pengelolaan diri, yakni pada Ridwan, Valentino, Faisal, Kaira, Intan, dan Farid. Sebagaimana apa yang dikatakan The Liang Gie, bahwa melalui teknik pengelolaan diri, anak lebih terdorong untuk berperilaku lebih baik, mengatur dan mengendalikan dirinya, dan memperbaiki serta mengembangkan kepribadian diri dalam kehidupan kesehariannya (Liang Gie, 2000:77-78). Teknik pengelolaan diri melalui pelatihan keterampilan sosial dari hasil penelitian ini dapat dilihat dari perubahan yang cukup signifikan pada Valentia, Naya, Isa, dan Yusuf. Hal ini sebagaimana apa yang dikatakan Gresham dan Elliot bahwa dengan pelatihan keterampilan, anak mampu merasakan perilaku dalam konteks situasi tertentu dalam dirinya, sehingga bisa berinteraksi dengan lingkungan sosialnya, seperti anak menilai orang lain dengan berpikir positif dan bersikap sosial lainnya. Sikap sosial ini sangat penting bagi seseorang, karena dengan sikap sosial seseorang akan cenderung bersikap dengan cara tertentu kepada orang lain. Orang itu akan lebih terarah kepada tujuan sosial yang berbanding terbalik pada tujuan individualnya (Huriyah, 2019:77).

Perubahan yang dihasilkan dari modifikasi perilaku tersebut tidak terlepas dari peran dan tanggung jawab anggota keluarga, khususnya peran orang tua. Kesadaran orang tua dalam membina dan mendidik anak secara holistik dan kontinyu menjadi sangat penting demi terwujudnya perilaku positif terhadap anaknya dalam kehidupan keseharian. Oleh karena itu, 
modifikasi perilaku ini sebagai upaya mengubah perilaku dan emosi manusia (yang dalam hal ini adalah anak-anak) dengan cara yang menguntungkan berdasarkan prinsip-prinsip belajar. Modifikasi perilaku ini untuk mengubah perilaku maladaptif seseorang dengan melemahkannya dan perilaku adaptif seseorang ditimbulkan dengan baik, sehingga seseorang tersebut bisa menjalani kehidupan yang lebih baik secara individual maupun sosialnya.

\section{PENUTUP}

Perubahan tingkah laku dari perilaku maladaptif menuju perilaku adaptif dengan melakukan modifikasi perilaku, yakni menggunakan teknik pengelolaan diri dan keterampilan sosial akan mengubah pribadi anak dalam konteks mengantisipasi mereka supaya tidak berperilaku negatif. Modifikasi perilaku tersebut telah menghilangkan perilaku-perilaku yang negatif serta menumbuh-kembangkan perilaku yang positif. Karena pada dasarnya hal ini merupakan pengaturan segala hal yang mencangkup pikiran, waktu, tempat, dan sumber daya lainnya. Demi terwujudnya modifikasi perilaku yang baik, maka harus ada komunikasi dan kerja sama antar anggota keluarga. Pemberian motivasi, pengertian, dan pengawasan yang dilaksanakan secara kontinyu akan mampu mengubah perilaku anak menjadi pribadi yang lebih adaptif dan produktif ke depannya.

\section{DAFTAR PUSTAKA}

Aisyah, Siti. (2019). Pendidikan Fithrah dalam Perspektif Hadist (Studi tentang Fithrah Anak Usia 7 - 12 Tahun). Al-Adzka: Jurnal Ilmiah Pendidikan Guru Madrasah Ibtidaiyah. Vol. 9. No. 1.

Faz, Gerry, Olvina. (2015). Penerapan Metode Modifikasi Perilaku Pembentukan (Shaping) untuk Membentuk Perilaku Sosial Anak dengan Ketidakmampuan Intelektual Ringan. Tabularasa. Vol. 10. No. 2.

Gichara, Jenny. (2006). Mengatasi Perilaku Buruk Anak. Jakarta : Kawan Pustaka.

Gie, The Liang. (2000). Cara Belajar yang Baik bagi Mahasiswa edisi kedua. Yogyakarta: Gajdah Mada University Press.

Huriyah. (2019). Menumbuhkan Sikap Sosial melalui Pembelajaran IPS Siswa SD Home Schooling Primagama Banjarmasin. Al-Adzka: Jurnal Ilmiah Pendidikan Guru Madrasah Ibtidaiyah. Vol. 9. No. 2.

Jamal Abdurrahman, Syaikh. (2010). Islamic Parenting Pendidikan Anak Metode Nabi. Solo : PT. Aqwam Meia Profetika.

Jembarwati, Otih. (2015). Modifikasi Perilaku untuk Mengenal Diri dalam Membentuk Sikap Positif Peserta Didik. Psympathic. Jurnal Ilmiah Psikologi. Vol. 2. No. 1.

Lickona, Thomas. (2013). Education for Character, terj. Juma Abdu Wamaungo. Jakarta: Bumi Aksara.

Majid, Abdul. (2014). Pembelajaran Tematik Terpadu. Bandung: PT. Remaja Rosdakarya.

Makhfud. (2011). Hubungan antara Manajemen Diri dengan Prokratisasi Akademik pada Siswa Aktivis BEM IAIN Sunan Ampel Surabaya. Surabaya: UIN Sunan Ampel.

Moelong, Lexy J. (2011). Metodologi Penelitian Kualitatif. Bandung: PT Remaja Rosdakarya.

Mulyana, E. (2016). Manajemen Pendidikan Karakter. Jakarta: Bumi Aksara.

Purwanta, Edi. (2012). Modifikasi Perilaku Alternatif Penanganan Anak Berkebutuhan Khusus. Yogyakarta: Pustaka Belajar.

Retnowulan, Dyah, Ayu. (2013). Penerapan Strategi Pengelolaan Diri untuk Mengurangi Kenakalan Remaja Korban Broken Home. Jurnal BK Unesa. Vol. 3. No. 1.

Sugiyono. (2015). Metode Penelitian Pendidikan. Bandung: Alfabeta. 
Sugiyono. (2018). Metode Penelitian Kuantitatif, Kualitatif, dan Kombinas (Mixed Methods). Bandung: Alfabeta.

Sulistyoko, Arie. (2018). Tanggungjawab Keluarga dalam Pendidikan Anak di Era Kosmopolitan (Telaah Tafsir Kontemporer Atas Surat At-Tahrim Ayat 6). Iqro: Journal of Islamic Education, Vol. 1 No. 2. 